\title{
BUSINESS PERFORMANCE OF DUCK FARMERS IN BREBES REGENCY- CENTRAL JAVA
}

\author{
W. Sumekar ${ }^{1}$, Isbandi $^{1}$, U. Atmomarsono ${ }^{1}$ and I. Susilowati ${ }^{2}$ \\ ${ }^{1}$ Faculty of Animal and Agricultural Sciences, Diponegoro University, \\ Tembalang Campus, Semarang 50275 - Indonesia \\ ${ }^{2}$ Faculty of Economics and Business, Diponegoro University, \\ Tembalang Campus, Semarang 50275 - Indonesia \\ Corresponding E-mail:wulan_sumekar@yahoo.co.id
}

Received January 11, 2013; Accepted May 29, 2013

\begin{abstract}
ABSTRAK
Peternak itik di Kabupaten Brebes belum mampu mengatasi dinamika usaha dengan permasalahan utama bibit dan pakan. Tujuan penelitian adalah untuk menganalisis kinerja usaha ternak itik di kabupaten Brebes. Efisiensi teknis dan ekonomis dihitung untuk mengetahui status kinerja usaha ternak itik. Penelitian telah dilakukan pada empat Kelompok Tani Ternak Itik (KTTI) tergolong aktif di Kabupaten Brebes, Jawa Tengah. Penelitian menggunakan metode survey dengan menggunakan 123 peternak anggota kelompok sebagai responden. Hasil penelitian menunjukkan bahwa peternak belum seluruhnya melakukan kegiatan usaha secara efisien (rata-rata nilai efisiensi teknis 0.9981). Hal ini terjadi karena penguasaan jumlah itik, pemberian pakan hijauan dan penggunaan teknologi belum optimal. Nilai return to scale usaha ternak itik sebesar 1.0868 menunjukkan bahwa masih ada peluang untuk meningkatkan produksi. Penelitian ini merekomendasikan perlu menata manajemen produksi untuk meningkatkan kinerja usaha dengan mengoptimalkan penguasaan jumlah itik, pemberian pakan hijauan dan penggunaan teknologi
\end{abstract}

Kata Kunci : efisiensi, itik, kelompok tani ternak, kinerja,usaha

\begin{abstract}
The duck farmers in Brebes Regency has not been able to deal with the business dynamics with the main problems in feed and Day Old Duck (DOD).The aim of the research was to analyze the business performance of duck farmer in Brebes Regency. The technical and economical efficiency was calculated to find out the status of duck farmer's business performance. The research was conducted to four most active duck farmer groups (KTTI) in Brebes Regency. The research was done based on survey method with 123 duck farmers of the group member as the respondents. The research results show that not all of the duck farmers performed their business efficiently (the average technical efficiency is 0.9981) since the number of duck ownership, forage, and the use of technology were not optimum yet. The return to scale value of the duck farming businesses was 1.0868 , which showed the presence of opportunity to increase production. This research recommends that it is necessary to manage the production management in order to increase business performance by optimizing the number of duck ownership, forage feed, and the use of technology.

Keywords: efficiency, business, duck, farmer group, performance, business
\end{abstract}

\section{INTRODUCTION}

Agricultural sector, particularly duck farming, is the commodity known widely and managed by some people in rural areas as income sources. The duck farming business faces the people's demand dynamic shift to duck products. The increasing of preference of people in Central
Java to duck meat is, in fact, followed by the decrease of duck egg production in 2009/2010 by $7,124,967 \mathrm{~kg}$. People's preference for duck meat causes unbalance between the increasing of duck production and duck slaughtering by 172,852 ducks in 2009/2010. This condition is suspected to encourage the interest competition in using DOD for the purpose of egg production and meat 
production (Dinas Peternakan dan Kesehatan Hewan Propinsi Jawa Tengah, 2011).

Brebes Regency is the region with the highest population duck compared to other regencies in Central Java. The duck population in 2010 was $4,487.06$ ducks with the egg production $22,673,985 \mathrm{~kg}$. The people's demand to duck products has not been responded by farmers through the duck farmer group in Brebes Regency. The duck farmers are still oriented to duck farming business as egg producers. It is shown from the ownership of mature female duck by $90.34 \%$ (Dinas Peternakan dan Kesehatan Hewan Propinsi Jawa Tengah, 2011). The existence of duck farming as a resource was also threatened to be extinct as shown by the number of female ducks bought and sold by $82.69 \%$ and $64.42 \%$, respectively. On the other hand, the sale of female duck by age was $56.46 \%$ as young and mature duck. The decrease also occurred in DOD quality as shown by the origin of DOD was $47.37 \%$ and $52.63 \%$ was from the local traders or those who came from out of town and other places.

The weather factors frequently affecting agricultural and farming production are rainfall and drought. The duck management from an area to other still main choice of farmer in rice fields.

The difference of duck demand for egg production and DOD causes difficulties for farmers to get quality of DOD. The unstable egg production and the business orientation of duck farmers are only for consumed egg production. Therefore, the question is has the business performance of duck farming been efficient?. On the basis of reason above, this study was conducted.

\section{MATERIALS AND METHODS}

Brebes Regency was chosen as the research location because it is the regency in Central Java with the most duck population. The research was conducted from February to May 2011. The duck farmer population as the research target was the duck grooup farmers (in Indonesian is called Kelompok Tani Ternak Itik or KTTI) in Brebes Regency. Four active KTTIs were chosen (Handojono, 2011); 3 KTTIs in the areas bordering the lowland North Coast of Java Sea (KTTI 'Adem Ayem' in Bulakamba Sub-District, KTTI 'Mengkarsari' in Warnasari Sub-District, and KTTI 'Maju Jaya' in Brebes Sub-District), and 1 KTTI located in upland (KTTI 'Bebek
Umbaran' in Tonjong Sub-District). The numbers of samples were 123 duck farmers. The data wer collected through interview using questionnaires, documentation, and observation.

The business performance of duck farmers was measured based on the efficiency of input use to output technically. Technical efficiency was analyzed using frontier production function supported by f.4.1c program (Battese and Coelli, 1995; Coelli, 1996), namely:

a. The form of Stochastic Production FrontierTechnical Efficiency Model (SPF-TE) used in the research was as follows:

Ln $Y=b_{0}+b_{1} \operatorname{LnX}_{1}+b_{2} \operatorname{LnX}_{2}+b_{3} \operatorname{LnX}_{3}+$ $\mathrm{b}_{4} \mathrm{LnX}_{4}+\mathrm{b}_{5} \mathrm{LnX}_{5}+\mathrm{b}_{6} \operatorname{LnX}_{6}+\mathrm{b}_{7} \operatorname{LnX}_{7}+$ $\mathrm{b}_{8} \operatorname{LnX}{ }_{8}+\mathrm{b}_{9} \operatorname{LnX} X_{9+} \mathrm{b}_{10} \operatorname{LnX} X_{10}\left(\mathrm{v}_{\mathrm{i}}-\mathrm{u}_{\mathrm{i}}\right)$

Where:

$\mathrm{Y} \quad=$ estimated production

$\mathrm{b}_{0} \quad=$ intercept

$\mathrm{b}_{1}-\mathrm{b}_{10}=$ regression coefficient

$\mathrm{X}_{1} \quad$ number of ducks

$\mathrm{X}_{2}=$ labor

$\mathrm{X}_{3} \quad=$ rice bran

$\mathrm{X}_{4} \quad=$ parched rice

$\mathrm{X}_{5} \quad=$ sumpil shell (Melania testudinaria)

$\mathrm{X}_{6}=$ trash fish

$\mathrm{X}_{7} \quad$ = forage

$\mathrm{X}_{8} \quad=$ technology

$\mathrm{X}_{9} \quad=$ shed field

$\mathrm{X}_{10}$ = farming experience

In accordance with the procedure of multiple regression analysis, regression coefficient test was conducted partially ( $\mathrm{t}$ test) with the purpose to recognize the indicators of production factors whether they simultaneously or partially have the effect on production significantly. Production is efficient technically if the production elasticity (PE) value is between 0 and $1(0<\mathrm{EP}<1)$ so that the value of $0<\mathrm{PE}<1$ is rational stage.

b. Return to Scale Analysis

Return to Scale (RTS) analysis was conducted by adding regression coefficient or elasticity parameter or partial technical efficiency.

RTS $=\beta_{1}+\beta_{2}+\beta_{3}$

If $\beta_{1}+\beta_{2}+\beta_{3}=1$, it means that the proportion of additional input is proportional with the additional input obtained (Soekartawi, 2003). 


\section{RESULTS AND DISCUSSION}

\section{Respondent's Characteristics}

The business of duck farming had been performed by $73.18 \%$ of duck farmers having the experience of more than 5 years in duck farming and $20.32 \%$ of farmers stated that the main reason of their duck farming was because of parents' inheritance. $59.35 \%$ of farmers were from young to old age (the age of 19 to 57 years old) and $76.25 \%$ of farmers were in low education (fewer than 9 years). $81.30 \%$ of farmers relied on duck farming as main job. On the basis if the respondent's characteristics, so duck farming is highly beneficial socially and economically for duck farmers in Brebes Regency.

\section{The Raising Pattern of Duck Farming}

Duck farming business in Brebes Regency are mostly located in the lands along the river bank in line with the natural condition of Brebes Regency having 22 rivers directly connected to Java Sea. The integration of river current with the sea is the suitable place for duck habitat. In average, the farmers have 677.65 ducks with the manpower of 7.7 hours per person per day or equal to 1.1 Male Working Days. The workers' activities in duck farming business in Brebes Regency with the most time share are in the activity of herding ducks from morning to afternoon (5 hours per person per day in average). This condition indicates that the farmers still rely on the nature mercy to manage their farming business. The farmers' intervention in managing duck farming is relatively low, that is 85 farmers (69.10\%) applied the semi intensive raising pattern. Regarding the interview results with the farmers, it was found that the ducks herded are stronger and increase egg production and the egg price is higher than the intensive ones.

\section{Duck Feeding Pattern}

The farmers used the type of feed for ducks by using local and natural feed, such as rice barn, parched rice, sumpil shell, trash fish, and forage feed. The composition of the duck feeds as shown in Table 1.

The average of feed per day per ducks was $170.08 \mathrm{~g} / \mathrm{ducks} /$ day. The feeding condition is not in line with Anggorodi's statement (1995), which is $225 \mathrm{~g} /$ ducks/day. The feed component with the most energy is from rice barn and the protein source is from trash fish. Table 1 shows that the percentage of rice barn use in the feed is $76.70 \%$.
It is not in line with the research results of Rochjat (2000) that the rationing of rice barn until $75 \%$ to egg laying ducks does not disrupt egg production as long as the other nutrition is sufficient.

The feeding to ducks was suspected because of the limitation of the farmers' knowledge on the duck need. The farmers did not have the guidance for appropriate feeding (quality and quantity). In addition, the farmers just relied on the experience in duck farming business to manage it including in feeding as shown that $75.61 \%$ of the farmers have the experience of more than 5 years.

On the other hand, the nutrition content of feed given to ducks based on the calculation of feed nutrition composition by Hartadi et al. (2005) is found that the ration nutrition content with the energy content is $2989.23 \mathrm{Kcal} / \mathrm{kg}$ and the crude protein content is $31.69 \%$. It is not in line with the research results of Subiharta et al. (2006) that the ducks raised intensively in Brebes Regency was given the ration with the protein content of $12-15 \%$.

\section{Duck Farming Productivity}

The respondents' duck farming productivity is the indicator of technology mastery level in managing duck farming related to the overall management results in managing their business. Table 2 shows the number of respondents by the class of duck egg production in Brebes Regency.

The class of duck egg production from the duck farmers by the respondents is relatively low. On the basis of the average number of the respondents' duck ownership is 467.76 ducks with the average egg production each day 278.58 eggs, the average productivity of duck farming is relatively medium; $60 \%$ each day. As stated by Subiharta et al. (2006) that the ducks raised intensively in Brebes Regency was given the ration with $76 \%$ duck farmers in Brebes Regency were not used the best ducks.

\section{Duck Farming Business Performance}

Business performance was measured based on technical efficiency in using production input in relation with egg production and the return to scale value of the duck farming. The estimation of production function are presented in Table 3.

The production function in the duck farming businesses in Brebes Regency based on Table 3 can be formulated as follows:

$\ln \mathrm{Y}=\ln 0.9210+0.5933 \ln \mathrm{X}_{1}+0.1131 \ln \mathrm{X}_{2}+$
$0.0538 \ln \mathrm{X}_{3}+0.08021 \ln \mathrm{X}_{4}+0.05221 \ln \mathrm{X}_{5}-$ 
Table 1. The Duck Feed Ingredients

\begin{tabular}{lcc}
\hline Duck Feed & $\begin{array}{c}\text { Feeding } \\
\text { Percentage } \\
\text { to total feed } \\
(\%)\end{array}$ & $\begin{array}{c}\text { Average } \\
\text { Quantity of } \\
\text { Feeding } \\
\text { (g/duck/day) }\end{array}$ \\
\hline Rice Barn & 45.04 & 76.60 \\
Parched Rice & 8.86 & 15.07 \\
Sumpil Shell & 3.74 & 6.36 \\
Trash Fish & 39.18 & 66.63 \\
Forage & 3.19 & 5.42 \\
$\quad$ Total & 100.00 & 170.08 \\
\hline
\end{tabular}

Table 2. The Number of Respondents by the Class of Duck Egg Production

\begin{tabular}{ccc}
\hline $\begin{array}{c}\text { Class of Duck Egg } \\
\text { Production } \\
\text { (egg/day) }\end{array}$ & $\begin{array}{c}\text { Number of } \\
\text { Respondents } \\
(\mathrm{n})\end{array}$ & $\begin{array}{c}\text { Percentage } \\
(\%)\end{array}$ \\
\hline$<50$ & 2 & 1.62 \\
$50-190$ & 54 & 42.28 \\
$200-240$ & 22 & 17.89 \\
$250-290$ & 14 & 11.38 \\
$>300$ & 29 & 23.57 \\
\hline
\end{tabular}

$0.00121 \ln \mathrm{X}_{6}+0.1954 \ln \mathrm{X}_{7}+0.03681 \ln \mathrm{X}_{8}-$ $0.0559 \ln \mathrm{X}_{9}+0.3095 \ln \mathrm{X}_{10}$

Then, from the production function, the return to scale (RTS) value is found; $\sum \beta=0.5933$ $+0.1131+0.0538+0.0802+0.0522+0.0012$ $+) .1954+0.0368-0.0559+0.3095=1.0868$. This result showed that the use of production factor is in the stage of increasing return to scale shown by the elasticity coefficient of RTS 1.0868 (Ep>1). It means, the additional proportion of production factors will result in more additional proportion of egg production. Additional number of ducks, forage feed, and technology can increase duck production. Whereas, additional use of other production factors, particularly trash fish, require precautionary to get profitable additional production. Additional number of ducks to increase egg production is in line with Suryanto (2007) that additional number of livestock will
Table 3. The Estimation of Frontier Production Function

\begin{tabular}{lc}
\hline Variable & $\begin{array}{c}\text { Frontier Function } \\
\text { Coefficient } \\
\mathrm{n}=123\end{array}$ \\
\hline Constants & 0.9210 \\
The number of ducks & $0.5933^{* *}$ \\
Labor & 0.1131 \\
Rice barn & 0.0538 \\
Dry rice & 0.0802 \\
Small shell & 0.0522 \\
Trash fish & -0.0012 \\
Forage & $0.1954^{* *}$ \\
Experience & 0.04 \\
Lands (D1) & -0.06 \\
Technology $(\mathrm{D} 2)$ & $0.3095^{* *}$ \\
\hline **Significant $(\mathrm{P}<0.01)$ &
\end{tabular}

increase business profit. Additional forage feed is not in line with Mangisah et al. (2009) suggesting that forage feeding has weaknesses because high crude fiber content can decrease feed digestion. Processed feed of forage in the form of fermented hyacinth leaves can be used as the material for duck ration until the percentage of $17 \%$.

The analysis results of technical efficiency of the entire farmers showed that the production process of duck farming products was not efficient. Refer to Table 3, as the whole, the production process of duck farming business in Brebes Regency resulted in the average value of technical efficiency (TE) was about 0.9981. It shows that the farmers have not entirely performed the duck farming business efficiently. It occured because the farmers have not used production factors appropriately and correctly, namely; the number of ducks should be increased, the inappropriate use of fed in the quantity and quality. It might be caused by the low educational level of farmers so that the technology adaptation on duck farming business tends to be static. As stated by Indarsih and Suyatman (2012), that knowledge, skill and capital are some limitations for the development of integrated contract and independent broiler production in East Lombok. 


\section{CONCLUSION}

The average productivity of ducks each day is $63.58 \%$. The egg production from the duck farming business was positively associated with the level of production input use. The business performance of farmers technically is not efficient $(0.9981<1)$. The production inputs having the most significant role are the number of ducks, forage feed, and technology. The use of feed both in quantity and quality was not appropiate.

\section{ACKNOWLEDGMENTS}

The research was supported by 'Beasiswa BPPS' scholarship Doctoral Program from Higher Education General Directorate, Ministry of Education, Republic of Indonesia. The authors are thank to Planning and Overseas Cooperation Bureau (BPKLN), Ministry of Education, Republic of Indonesia for providing research funding of P3SWOT 2011

\section{REFERENCES}

Anggorodi H.R. 1995. Nutrisi Aneka Ternak Unggas. PT. Gramedia Pustaka Utama, Jakarta

Battese, G.E. dan T.J. Coelli. 1995. A model for technical inefficiency effects in a stochastic frontier production function for panel data. Emperical Economics 20 : 325-332

Co Coelli, T.J. 1996. A Guide to Frontier Version 4.1 : A Computer Program for Stochastic Frontier Production and Cost Function Estimation. Department of Econometrics, University of New England, Australia. http

://www.une.edu.au/econometrics/cepawp.ht $\mathrm{m}$

Dinas Peternakan dan Kesehatan Hewan Propinsi Jawa Tengah. 2011. Statitik Peternakan Jawa Tengah 2011. Dinas Peternakan dan Kesehatan Hewan Propinsi Jawa Tengah,
Ungaran.

Handojono. 2011. Inventarisasi Kelembagaan Kelompok Tani Ternak Kabupaten Brebes Tahun 2011. Dinas Peternakan Kabupaten Brebes

Hartadi, H., S. Reksohadiprodjo and A.D. Tillman. 2005. Tabel Komposisi Pakan Untuk Indonesia. Gadjah Mada Univ. Press, Yogyakarta.

Indarsih, B. and W. Suryatman. 2012. Performance of integrated contract and independent broiler production in East Lombok, West Nusa Tenggara. J. Indonesian Trop. Anim. Agric. 37(1):50-58

Mangisah, I, B. Sukamto and M. H. Nasution. 2009. Implementation of fermented Enceng Gondok in duck ration. J. Indonesian Trop. Anim. Agric. 34(2):127-133

Saptana. 2010. Tinjauan konseptual mikro-makro daya saing dan strategi pembangunan pertanian. J. Forum Penelitian Agro Ekonomi. 28(1):1-18

Saptana and Sumaryanto. 2009. Kebijakan antisipatif terhadap peraturan dan kebijakan perunggasan pemerintah DKI 2010. J. Analisis Kebijakan Pertanian. 7(4):319-335

Soekartawai, 2003. Teori Ekonomi Produksi Dengan Pokok Bahasan Analisis Fungsi Cobb-Douglas. Jakarta, Rajawali Press

Subiharta, Sarjana, D. Pramono, D. M. Yuwono and Hartono. 2006. Penilaian petani terhadap kualitas bibit Itik Tegal. Proc. Lokakarya Unggas Air II, Bogor. P. 181187

Suryanto, B. 2007. The break even point analyses of Ettawa crossbreed agribusiness in Sambong District Blora Regency Central Java Provence. J. Indonesian Trop. Anim. Agric. 32(2):106-111

Yusdja Y. and B. Winarso. 2009. Kebijakan pembangunan sosial ekonomi menuju system peternakan yang diharapkan. J. Analisis Kebijakan Pertanian. 7(3):269-281 